\title{
Labour
}

Journal of Canadian Labour Studies

Le Travail

Revue d'Études Ouvrières Canadiennes

\section{Eric Blanc, Red State Revolt: The Teachers' Strike Wave and Working-Class Politics}

\section{Paul Bocking}

Volume 85, printemps 2020

URI : https://id.erudit.org/iderudit/1070921ar

DOI : https://doi.org/10.1353/1lt.2020.0020

Aller au sommaire du numéro

Éditeur(s)

Canadian Committee on Labour History

ISSN

0700-3862 (imprimé)

1911-4842 (numérique)

Découvrir la revue

Citer ce compte rendu

Bocking, P. (2020). Compte rendu de [Eric Blanc, Red State Revolt: The Teachers' Strike Wave and Working-Class Politics]. Labour / Le Travail, 85, 311-314.

https://doi.org/10.1353/llt.2020.0020 d'utilisation que vous pouvez consulter en ligne.

https://apropos.erudit.org/fr/usagers/politique-dutilisation/ 
chances are near zero. The only time Childress shifts from the perspective of the individual consumer, it is to occupy the mind of a college administrator. This is a telling failure of imagination.

It is refreshing to see Adjunct Underclass making class a central concept. Unfortunately, the class analysis is more of a schematic of the American ecology of higher education than a class analysis per se. Childress posits that the role of adjuncts differs in community colleges, state colleges, liberal arts colleges, and research universities: in the former, poorly paid middle-aged adjuncts teach remedial courses to working-class students; at the latter, harried young post-docs and grad students teach undergrads while their supervisors oversee research teams and give keynote addresses. Childress's analysis is very much hewed to the American context, where institutions of highly learning operate with vastly unequal funding and serve entirely separate student populations. Canada's universities are comparatively uniform, and so the class composition of our students and the working conditions of adjuncts at different universities are less easily schematized.

This connects with a claim Childress makes early on and never really elaborates on; that colleges' betrayal of their faculty, their students and their mission, were "crimes without criminals." Administrators, Childress notes breezily, deal with a lot of uncertainty, including funding changes and enrolment changes, and so they cushion themselves by employing educators on short-term contracts. Even if we accept this argument, why do funding changes happen? Harvard's endowments don't change from year to year, but publicly funded universities are at the whim of legislatures and the platforms of the parties therein. Universities increase their complement of contract faculty because they can't replace tenure-track faculty because provincial governments don't fund post-secondary education adequately. Treating austerity in higher education as a given is a common administrative stance, but if we're assigning blame it seems odd to leave out the politics of public finance.

The other element the book leaves out, somewhat oddly, is unions. In Canada, where adjunct faculty are often organized, the difference between unionized and non-unionized contract instructors is clear; collective agreements that outline some form of non-tenure permanency, or that mandate departmental hiring committees to convert course instructors into permanent faculty, effectively use the threat of a strike to alter the facts of contingency. It's a real poverty of analysis if, in a situation where a movement could be very effective, you limit your understanding of agency to individuals and then reduce their possible actions to a shrug.

David Tough

Trent University

\section{Eric Blanc, Red State Revolt: The Teachers' Strike Wave and Working-Class Politics (New York: Verso 2019)}

THE STRIKE WAVE of teachers across southern US states in the spring of 2018 was arguably one of the most important events for the American labour movement so far in the early 21st Century, contributing to the highest national strike rate since 1982. Alongside a strong rebuke to years of cuts to public education funding, the struggle centred in regions with weak unions and entrenched Republican administrations. Claims that the Janus Supreme Court decision would spell the end of organized labour have been refuted by the fact of successful, 
unsanctioned mass strikes in right-towork states.

Blanc's book has made a splash as the definitive account of Red 4 Ed -introduced by the West Virginia initiators of the movement in tribute to their state's historic miners' struggles where unionists wore red bandanas. While following the strikes on the ground, Blanc was open about supporting the movement, and also drew on his background as a former high school teacher. This engagement helped earn the trust of grassroots organizers, giving him access to closed strategy sessions that considerably enriched the book's insights. It has received endorsements by Diane Ravitch, the most prominent US critic of the privatization of public education and Jane McAlevey, one of the most prominent contemporary US labour strategists. With its accessible style and focus on practical lessons, it has been promoted by the US labour left. As awareness of the Red 4 Ed strikes spread to Ontario, unions protesting Doug Ford's Conservative government wore red in tribute. Many activist teachers in Ontario have picked up the book, eager for lessons relevant to their context.

Red State Revolt's key point is how the large scale and intensive organizing of teachers and education workers in West Virginia and Arizona, and to a lesser degree in Oklahoma, revived working class left politics in these generally conservative states. Participation in the strikes led many to withdraw support from pro-austerity and pro-privatization Republicans. The strikers built on frustration over the degradation of teaching - evident in their paltry salaries and the thousands of unfilled vacancies in each state (which also reduced fears of reprisals). Blanc argues that the walk outs avoided mass repression because officials feared it would generate greater public support. Like many public sector workers, teachers are socially embedded in the community in which they work. With a successful strike not affecting private profits but "creating a social and political crisis," (45) winning and maintaining public support is essential. During the walkout, teachers and supporters distributed meals to the impoverished families that they served. Teachers of Latino background organized with the predominantly Latino families whose children attended public schools in Arizona, ensuring their majority support.

The education unions had not been combative for decades. Their leadership's vision of what was politically possible had narrowed in tandem with the underfunding of public education. A minority of school employees were members and the unions held limited collective bargaining rights. With the exception of West Virginia, there was limited precedent of collective action within living memory. Yet once the grassroots organizing gathered momentum, the official state union leaders engaged and used their formal structures to launch the strike and negotiate with state authorities. The continuing strength of grassroots organizing was critical. A pivotal moment in West Virginia which ultimately led to victory was a mass rally at the state legislature that received news of an ambiguous settlement by demanding union leaders go "back to the table".

Drawing on a comparative social movements approach, Blanc assesses what led to the most successful cases of West Virginia and Arizona where strikes yielded significant salary increases, defeated a barrage of Republican threats to public schools, and built lasting movements. The outcome was more ambiguous in Oklahoma, where teachers won a raise, but the movement demobilized. Blanc devotes nearly half of the book to an ethnography of the social networks that made the difference, arguing for the importance of a "militant minority" that 
was highly motivated and radicalized, often through the growing Democratic Socialists of America (of which Blanc is a member) following the 2016 Bernie Sanders presidential nomination campaign. Overlooked in many accounts was the decision by local activists to emphasize building a strong network of leaders at each school site, often through old fashioned, face to face meetings. What is more well known is that these leaders connected through social media, creating agile state-wide networks. But what was crucial is that these grassroots leaders already had strong credibility with their colleagues. Most also began to work within the unions.

In Oklahoma, Blanc found in-person school-site organizing was neglected. Facebook groups with thousands of teachers materialized within days as excitement followed West Virginia's strike. These platforms were controlled by the individuals who created them, who were reluctant to engage with the existing unions. When the union leadership compromised with the state government despite meeting fewer of the movement's demands, strikers were dissatisfied but unable to draw on the workplace relationships necessary to take a larger risk of staying out.

The most successful actions incorporated all school staff, with bus drivers especially strategic in rural West Virginia. Their pledge to join the walkouts lead superintendents to close the schools. Building this solidarity was difficult. Teachers benefited from much greater public prominence and continued to be paid during some walk outs while lower waged support staff were not, exacerbating class and sometimes racial divisions. School support staff in Canada struggle with similar issues.

The defining issues of the strikes were ostensibly 'bread and butter'. Salaries were among the very lowest in the US and benefits were under threat. Proponents of social movement unionism emphasize demands likely to resonate with the broader public. "Bargaining for the common good" is perhaps most associated with the Chicago Teachers Union and the United Teachers Los Angeles. Both went on strike in 2019 demanding smaller class sizes and more nurses, librarians, and social workers to assist students. Salary issues were deliberately pushed out of the spotlight. Strikes in these cities as well as the 'red states' enjoyed popular support. Context was key, with broad awareness in the red states that educators were so poorly paid that many held second jobs and vacancies struggled to attract applicants. Public support is just as strategic in Canada, with provincial governments routinely threatening and sometimes enacting Back to Work legislation despite Supreme Court rulings supporting the right to strike.

Of the many differences between the contexts of the southern states and Canada, the relative institutional strength of teachers' unions is one of the greatest, with membership nearly universal and often statutory. Navigating union structures is much more important for teacher activists looking to organize their colleagues. However, one wonders whether despite or maybe because of far greater institutional resources and status, unions in Canada may be more reticent than their southern colleagues to risk legal reprisals while confronting provincial governments like Ford's Conservatives in Ontario whose policies pose an existential threat to the teaching profession.

Blanc points out that popular support grew for the teachers during the strikes. The same has occurred for public sector workers in various provinces that have engaged in illegal strikes or political protests which slowed the momentum of aggressive governments, but not without considerable cost and risk. 
Blanc's conclusion is particularly relevant for senior union leaders in Canada who lean heavily on polling data and expensive consulting firms for their strategic analysis: "Rather than moderating one's politics to accommodate a mythical center, the only way to truly test the potentialities of popular support is through systematic organizing and the process of mass action itself." (81)

Paul Bocking

McMaster University

\section{Zachary J. Violette, The Decorated Tenement: How Immigrant Builders and Architects Transformed the Slum in the Gilded Age (Minneapolis: University of Minnesota Press 2019)}

IN THE FACE OF climate change and a housing affordability crisis, efforts to increase housing density have become among the most politically fraught issues facing North American cities today. These efforts have run up against an array of regulations and bylaws aimed at ensuring the continued dominance of the single-family home, justified by a desire to preserve the cultural (and socioeconomic) character of the middle-class, residential suburb. Opponents of densification sometimes allude to the enduring image of the New York City tenement and the evils that many perceive to be associated with it: overcrowding, crime, pollution, disease, and the threatening "other".

It was within this political context that I was excited to review Zachary J. Violette's new book The Decorated Tenement. The book is a re-evaluation of this iconic architectural form which continues to loom in the public consciousness as they still do over the streets of lower Manhattan. In his account of the emergence and spread of tenement buildings throughout late-19th century New York City and Boston, Violette finds familiar dynamics: rapidly growing cities in which working-class immigrants seek decent, affordable housing that reflects their tastes and lifestyle, and an established upper class threated by multifamily living who turn to government regulations as a way of reinforcing class boundaries.

Violette uses the term "decorated tenement" to describe the highly ornamented multi-family residential buildings that came to dominate the streets of New York City and Boston. He argues that these buildings represented modern, innovative solutions to housing the urban working class that made use of the latest amenities and incorporated elaborate aesthetic flourishes that appealed to a working-class desire for social mobility. Indeed, the buildings were built and designed for working-class immigrants by working-class immigrants. Violette points out that landlords often lived in their own buildings alongside their tenants. In this sense, he distinguishes decorated tenements from the mid-19th century "slum landscape" that they replaced. Prior to the rise of immigrantbuilt tenements, working-class housing consisted of dilapidated and haphazardly converted colonial-era buildings typically owned by wealthier, absentee landlords who wanted little to do with their properties and even less to do with the people who lived in them.

There is much to recommend in this book. The earlier chapters present a comprehensive account of the rise of the tenement in New York City and Boston, and how these buildings raised the living standards of the working class. This is followed by detailed descriptions of the decorated tenement itself, inside and outside. Discussions of room layouts and their role in working-class family life are accompanied by dozens of floor plans and interior photographs. As well, an entire chapter is dedicated to discussing the 